UDC: 321.61(091)

\title{
THE ENLIGHTENED ABSOLUTISM IN WESTERN EUROPE
}

\author{
Ivanka Vasilevska \\ Associate Professor, Faculty of Law "Iustinianus Primus", University "Ss Cyril and \\ Methodius", Skopje \\ i.vasilevska@pf.ukim.edu.mk \\ Sinisa Ivanovski, \\ Researcher, M-r \\ sinisha737@yahoo.com
}

\begin{abstract}
Enlightened absolutism represents a state policy which is implemented by the European forces in the duration of the 18th century. The chronological line of the enlightened absolutism covers the period of almost a half of century, from 1740 until 1789 i.e. to the start of the French revolution. The enlightened absolutism is a movement within the absolutism which follows after autocracy (fascism) and precedes the despotism. As founder and ideologist of the Enlightened absolutism is considered Thomas Hobbes with his master piece the Leviathan. The Leviathan according to Hobbes is a sovereign state power (the best form for him is absolute monarchy), which is needed in order to compel people of their obligations. The philosophy of this policy amounts to postulate which stipulates that the social reforms are possible but only through the state and for the state, this phenomena are social expression of the state interest and the state is the only possible protector of fundamental rights and freedoms of the man and the citizen is the state. In other words, according to the Enlightened absolutists (adherents of the absolute monarchy) "welfare in society "is possible only and only through the state and the regime that was established by the same. Because of all above mention, our interest in this paper is to explain the basic goal of the ideas of the enlightened absolutism.
\end{abstract}

Key words: 1) Enlightened absolutism; 2) French revolution; 3) Thomas Hobbes; 4) absolute monarchy

\section{Introduction}

Enlightened absolutism represents a state policy which is implemented by the European forces in the duration of the $18^{\text {th }}$ century. The chronological line of the enlightened absolutism covers the period of almost a half of century, from 1740 until 1789 i.e. to the start of the French revolution. The enlightened absolutism is a movement within the absolutism which follows after autocracy (fascism) and precedes the despotism. As founder and ideologist of the Enlightened absolutism is considered Thomas Hobbes with his master piece the Leviathan. The Leviathan according to Hobbes is a sovereign state power (the best form for him is absolute 
monarchy), which is needed in order to compel people of their obligations ${ }^{1}$. Therefore the people enter into an agreement for "their power and strength of a one person to be transferred to another person or a few people," and so create a state union. Otherwise, people would return to the natural state in which a man is wolf to a man, a form which in its characteristics resembles anarchy and it is approaching the initial state which does not suit of a being that is different from the other wildlife by his mental progress.

The philosophy of this policy amounts to postulate which stipulates that the social reforms are possible but only through the state and for the state, this phenomena are social expression of the state interest and the state is the only possible protector of fundamental rights and freedoms of the man and the citizen is the state. In other words, according to the Enlightened absolutists (adherents of the absolute monarchy) "welfare in society "is possible only and only through the state and the regime that was established by the same. The enlightened absolutism is a reflection of the policy of the French monarchs and has a its own diversity in the policy of absolutism in Prussia by Frederick II, the Habsburg Empire with Joseph II, in the Russian Empire with Catherine II as well as in other countries but with less intensity. The objective of enlightened absolutism is achieving of reorganization of the outdated social institutions of the Medieval and removal of some privileges of different strata of society, judicial reform, the introduction of global education in schools, reasonable mitigation censorship etc. ${ }^{2}$

Namely the formula for enlightened absolutism is given by Frederick II (17401786) and briefly consists of the phrase "The ruler is the first servant of the state". This defines the new position of the monarch requiring from him a constant care and so creating obligations for more harmonic development of society according to the norms of an enlightened world. Frederick II modernizes the legal system by introducing: a rule that the laws must be record, the independence of judiciary, he regulates the criminal law, introduced the equality before the laws and the abolition of the torture. Frederick II continues the policy of tolerance, within the framework of the economic policy which is geared towards the development of the industry and the trade, and the bourgeoisie are used to support the state. Although the bourgeoisie political rights are limited, it already provides access to the lower state services. The army in this period becomes the most important factor in the implementation of advanced policies due to the intensive warfare. The main gain of this war was the acquiring of the highly developed area Slezija and West Prussia in 1772 (the first separation of Poland). In the mid- $18^{\text {th }}$ century, Prussia became the rival of Austria regarding the leadership function over the German states. ${ }^{3}$

\footnotetext{
1 Raino, Malnes, Knut, Midgaard, „Политичка филозофија“, Феникс, Скопје, 2003. p. 92.

2 Билјана, Поповска, Историја на правото, Скопје, 2017. стр. 193.

3 J.M. Kelly, A short history of western legal theory, Oxford, 1992. p. 239.
} 
A policy of enlightened absolutism was exercised by Mary Theresa which ruled with Austria from 1740 to 1780 and her son Joseph II, who ruled to 1790. In the early $18^{\text {th }}$ century Austria is the largest state which is composed of the Holy Roman Empire and Central Europe. It continues to expand territorially and after the end of the war for the Spanish Succession in its possession passed some of the Italian states and Hispanic Holland. Following the war with the Ottoman Empire, Austria wins over parts of Serbia, Bosnia, Banat and Wallachia. The reforms of Mary Theresa and Joseph II succeed to strengthen the central government and to some extent to overcome the national intolerance. The role of central government was increasing at the expense of provincial privileges and Austria is transformed into a single state and gradually takes form of a unique state.

Elements of enlightened absolutism had developed in Russia with the rule of Catherine II (1762-1796). Catherine, a German princess, came to power after taking of the throne from her husband Peter III who was an incompetent and mentally unstable person. Catherine supports Voltaire, Diderot and has executed a number of reforms in the spirit of the enlightened absolutism. ${ }^{4}$

The three states -leaders of the enlightened absolutism - Russia, Prussia and Austria in 1772, 1793 and 1794 took advantage of the weakness of Poland and the start of the bourgeois revolution in France, so they divided Poland's territory thus the bulk of the territory was acquired by Russia. ${ }^{5}$

The aim of the enlightened absolutism is the adapting to the new requirements of the market economy which in this period is in an up growth, with consideration to maintain the highest level of privileges to the aristocracy. But the system of enlightened absolutism does not solve all the problems in the countries in which it evolves. Retention of certain limitations of the third class is conducted by keeping the basic privileges of the aristocracy and thus is retained even remount version of the absolutism. However, these limited reforms carried out under the influence of the ideas of the Enlightenment retain central European countries away from the whirlwind of political revolution that extends over France in the late 18th century. The bourgeois revolutions in those countries, mostly in the German states, was postponed more than half a century, and even in 1848-1849, the complex mixture of nationalism and socially - political demands will get the bourgeoisie in Central and Southern Europe to raise and start a revolution.

\section{The enlightened absolutism conducted through the prism of Napoleonic reign in Europe}

Enlightenment critique on the absolutism was socially caused by the occurrence of the civil society and provided that the absolutist state has taken in his hands once the indirect authorities, municipalities, provinces and social-class assemblies. The

\footnotetext{
4 Срђан, Шаркиђ, Општа историја државе и права, Београд, 1995. p. 132.

5 Филип, Лонгворт, „Стварање Источне Европе“, Clio, 2002. p. 215.
} 
period before the start of the French bourgeois revolution is characterized by the dominance of the tightening of appetites and opinions of two strong fetters forces in France. One of them was the position (entities in power) which seemingly through the manifestation of the ideas of enlightened absolutism intended to keep their positions, finding justification in history. On the other side was the aristocratic opposition or the old social classes which condemn the ideas of the enlightened absolutism marking it as concealed statics and autocracy. ${ }^{6}$

The tensions between the two above fetters forces as well as the powerlessness of the King of France from 1774 and the ignorance of the government to win the public opinion and the third social class led to bringing down of the reformations programs of the finance ministers Tirgu, Necker, Kolonej and Brynner and to the start of the revolution in July 1789 with the charge of Bastilja. ${ }^{7}$

The bourgeois revolution in France in the late 18th century is the most important event in the world history and opens a new era in the history of mankind. Apart from France, all of Europe is affected by political and economic upheaval that has carried out by the French bourgeois revolution. It could be said that it was a real people's revolution because the wide population was activated by setting its own demands as political as well as social. The revolution in its course turns into a bourgeois-democratic revolution. With the formation of the government and many state institutions, the main goals and objectives of the revolution were fulfilled and the independence of France was protected, which independence previously was threatened by the revolutions taking place in Europe. The major obstacle in accelerating the industrial development of France posed the old way of administrative management. The absolute monarchy which in the time of its occurrence was advanced, many years prior to the revolution became a main reason that impeded the development of the capitalism.

Throughout the $18^{\text {th }}$ century in France was not carried out any serious reform that will fit the size and the new needs of the country. The displeasure towards the monarchy over the centuries got tapering down nature of social class contradictions in the 18th century, mainly between the ruling social classes both nobles and clergy and third social class in which all other citizens belonged. The leader of the third class was the big bourgeoisie. The bankers, ship owners, tenants, tax inspectors, traders by their wealth and education were not at all behind the nobles which were in principle concentrated in Paris. But as the entire third class, the bourgeoisie felt that is being subordinated and humiliated due to the fact that the existing laws did not guaranteed any safety of their wealth. So, the bourgeoisie had wealth but no power and because of that fact, the bourgeoisie acted on behalf of the third social class and built a program for fighting the authoritarian order in France. In their demands, the

\footnotetext{
${ }^{6}$ И. Д. Мартисевич, С. В. Јушков, Н. П. Димитриевскиј, „Општа историја државе и права“ - втор дел, Београд, 1950. p. 239.

7 Ги, Антонети, „Современа политичка и општествена историја“, Арс Ламина, Скопје, 2011. p. 23.
} 
bourgeoisie demanded an abolition of all privileges and obstacles that have hindered the development of the capitalism in France and full political freedom. Initially, the vast majority had the feeling that the bourgeoisie had the same aims and objectives as well as the nobles, but it did not turned out as such. Before the revolution the workers in France did not constitute an independent social class because they lacked the organization and they did not stepped forward with specific class demands. The poor organization of the workers in this period was fiercely criticized. From time to time, secret worker associations acted on their behalf, but there was not a single organization that will act solely on behalf of the workers. However, workers' strikes were widespread in France, but in those collisions, the monarchy always stood by the bourgeoisie and the employers. Nevertheless the workers never considered the bourgeoisie as an enemy of but as such were considered the aristocrats, the nobles and the monarchy.

The French bourgeois revolution can be analyzed through three stages (phases). After two years of activity, which ended with the adoption of the Constitution in 1791, in which was implemented the revolutionary principle that the people have the constitutional power, comes the first phase related to the period 1791 to 1793 . At this stage it is important to mention the continuous shift of focus to political driving forces of the moderate civic center (Fejani, Girondists ) to radically democratic left (the Jacobins). Individual stages in this phase are:

- Declaration of war on Austria in 1792,

- The attack on the commune of Tulerius on August 10, 1792,

- The abolition of the monarchy and the election of the Republican National Assembly in September 1972 and

- Execution of the King in January 1973.

In the summer of 1973, the Jacobins led by Robespierre took the state power into their own hands. Thus begins the Dantons' terror from 1973 to 1974 and the second phase of the revolution. The Danton's terror begins with the Committee for public rescue and its fearsome activities, which ends in July 1974 with the beheading of Danton by supporters of Robespierre by guillotine. ${ }^{8}$

The third stage of the French bourgeois revolution was followed by the adoption of the new Constitution of 1975 as a result of past events and the weakening of the authority of the Directory. In that way the forms of classed civil society were outlined and the class civil society was more interested in achieving economic and social stability than conducting of the extreme political principles. Hence, the last third stage of the revolution is characterized by a decline in appetites and sympathy towards the movement and reducing the number of intellectuals' supporters that earlier with full swing acceded to the ideas and the principles of the French revolutionary movement.

The French bourgeois revolution with its flow and characteristics succeeded to exploit the potential and still to cause elevation of certain persons who thus mark

8 Birdsall, S. Viault, “Modern European History”, Mc Graw Hill, Inc. 1990. p. 178. 
the history. Napoleon Bonaparte, revolutionary and a landmark of France, within the events arising from the 18th century had a task to complete the initiated revolution. Since the revolution had abolished the intermediate organs of government, Napoleon was able to finish the centralization of the state administration started at the time of the absolutism and to build a complete, organized bureaucratic administrative system. Ensuring the freedom and the inviolability of the ownership, Napoleon has introduces the civil status as well as the liquidation of mortgages (with the conclusion of the Concordat with the Catholic Church in 1801). With the reign of Napoleon and his movement through the French revolution, the education has received a hierarchical form manifesting the principle of coercion which more or less has transferred itself in the other spheres of spiritual life. The reforms, such as in the economy and the finance, were not powerful enough to achieve major progress due to the influence of the imperial foreign and military policies. ${ }^{9}$

The position of Napoleon Bonaparte is defined as a very specific, because he and his ideas for the implementation of the core of the enlightened absolutism for creation of the internal relations in France occur later at the end of the revolution, and yet as strategist he dedicates attention to the foreign policy of France due to its visibly weakened position internationally. Thus, in order to achieve economic isolation of the English naval power and trade Napoleon establishes a link with Austria using military pressure and the marriage with Maria Luisa Hapsburg (1810), and with Russia he leads a successful bilateral policy.

Napoleon Bonaparte with his reign over European countries other than France achieved the goal to which France has aimed prior to the revolution and was hardly feasible due to the open and fierce resistance of the privileged social classes towards the enlightened absolutism. The desire of the states under Napoleons' reign to free themselves has grown more evident and they were inspired by patriotism, nationalism, the growing interest for spirituality and the church as well as the idea for rejection of the foreign power. ${ }^{10}$

In Central Europe the national movement, led by a thin layer of educated citizens, clerks and officers, under the foreign government increasingly gained more strength and had found support in the Prussian state which after the defeat in 1806 began to reorganize itself under the leadership of Count von Stein and Chancellor Carl August von Handerberg. The invasion in Russia in 1812 for submission of Imperial Russia brought twist by rounding the continental blockade. The abdication of Napoleon was a result of the unaccepted European coalitions for limitation of government on the territory of France. Napoleonic liberalism was not achieved and it was succeeded by the Caesarism of Napoleon III who along with Otto von Bismarck marked revolutionary European history in the 19th century. ${ }^{11}$

9 Eric, Hobsbawm, “The Age of Revolution 1789 - 1848”, Abacus, London, 2009. p. 98.

10 Ј. В. Тарлеа, Историја новог века, део први, Просвета, Београд, 1948. p. 191.

11 Хари, Хердер, „Европа у деветнаестом веку“, Clio, Београд, 2003. p. 284. 
Starting from the ideas of Jean Jacques Rousseau a new philosophy for changing the existing structural organization spreads guided by the question "in which way the authority can become legitimate." Since then no discussion was commenced on the removal of the differences inside the relevant fetters forces, but the value of those fetters forces. The influence of Napoleonic reign reflects in the manner of functioning of the army (military) with effect to the current principle of generally military service (which for the previous rulers was an indispensable instrument). ${ }^{12}$

The influence of the French Revolution differed significantly from area to area. In the Adriatic regions, in which the French government lasted longest, its impact was evident. In fact, the creation of the Illyrian provinces represents very important Illyrian or Yugoslav national step which shall be developed decades later. The reason for this is the fact that the French in these provinces have stimulated the cultural development. They established a network of secondary agricultural and trade schools. In those schools and in the newspapers that appeared within this period the national language was used. The French have subsidized the publication of dictionaries and grammar books of these nations and helped found the folklore theaters. Although the name "Illyria" for Napoleon did not have any national importance, in the Illyrian provinces Napoleon was quite respectable and desirable ruler. In one of the preserved public announcements of 10 March 1810, Colonel Manzhen told the people: "You are now part of a great nation, a confederation with big powerful empire; you became Illyrians and you must prove yourself worthy of the protection of Napoleon, the savior of your country." 13

For the Napoleonic reign and the French Revolution was believed to have opened the eyes of the world. Before that, nations knew nothing and people thought that the kings are gods of earth and everything they do, must be approved. After the changes brought by Napoleon, the ruling with the masses becomes more difficult and it is not simple at all.

\section{Attempts to conservation and restoration of the historical wheel of the Congress of Vienna in 1815}

Marked as winners of that which was proclaimed by Napoleon and during his first prosecution, without waiting for the official final defeat, the Bourbons in France, Spain and southern Italy, the Pope in Rome, the Savoian house in the kingdoms of Piedmont and Sardinia returned to the geographical scene. As the primary proponents for the return of the old regime which thought that there is a need for practical actions were Maternih from Austria, Hardenberg as representative of Prussia, Taljeran sent by Louis XVIII, Aleksandar I of Russia and Kaslrey from the United Kingdom. This

12 Henry, A. Kessinger, "Obnovljeni svijet, Matternich, Castlereaghi problem mira 1812-1822", Nakladni zavod Matice Hrvatske, Zagreb 1796. p.11.

13 Leften, Stavrijanos, “Balkan posle 1453 godina, Equilibrum”, Beograd 2005. p. 202. 
famous and historic quintuplet is associated with a remarkable event realized in Vienna known as the Vienna Congress 1814 - 1815. Rated as a positive development for the European continent, due to which there was peace nearly half a century, which although disturbed by the Crimean War of 1854 was so well founded that produced more than 60 years of stability in the mentioned areas. ${ }^{14}$

The balance created on the Congress of Vienna was not only a military but also an ethical one. The power and justice have been pretty consistent. The international order which is not considered to be a fair one, sooner or later shall be challenged, and therefore it needs to be intervened in the way in which a nation perceives the fairness of a world order in close relation with the domestic institutions and attitudes for tactical foreign policy issues. ${ }^{15}$

Following the Pit's plan the representatives have proven to be a successful creator of the desired balance without taking into account the creation of ethnically homogeneous nations. Thus the pre-revolutionary order was completely removed. England and the Habsburgs retrieved a significant part of their fragmented territories. The Union of Swiss cantons was reinstated and four free cities in Germany were restored. The aim was the establishment of a new balanced order that by its characteristics shall be more stable and stronger unlike to the order before the revolution. With the decisions of the Congress of Vienna, Austria has gained considerable expansion on the Balkan i.e. primarily in Dalmatia and other Malts areas with which a big influential power was gained in the Adriatic Sea and in the western part of the Balkan Peninsula. For these reasons it has become very important not to allow the Russian penetration over the Ottoman possession, primarily due to the huge number of Slavic subjects that within the vast Habsburg Empire could turn the Russian interest in to it. ${ }^{16}$

A synonym for the Congress of Vienna is the name of Metternich who had rationalist belief that laws and rights exist in nature and therefore cannot be imposed by regulations. Metternich in this period played a decisive role in maintaining international order and in the interpretation of the purpose of the Holy Alliance. The policy of Metternich consisted of using ethical consensus in order to avoid crises or if they can be avoided redirected them by discreetly supporting any country willing to accept the first strike of the collision. Metternich has supported the conservatism and according to him the true conservatism requires active policy and reforming should arise from the order, not from the will of individuals and with relying on the universal laws and not of strength.

\footnotetext{
14 J. M. Roberts, "The Penguin History of the World", Penguin Books, 1995. p. 725.

15 Иванка, Додовска, Рамнотежата на силите и Кримската војна од 1853 - 1856 Или како геостратешките интереси на Франиија и Англија го условија Виенскиот поредок? - Политичка мисла/ Political Thought ("The Balance of Powers: 200 years of the Congress of Vienna", edition of the Konrad Adenauer Foundation and the Institute for Democracy "SocietasCivilis", Skopje, 2015. p. 45.

${ }^{16}$ Leften Stavrijanos, ,Balkan posle 1453... p. 564.
} 
The creation of an international order very continues to support the balance of power based more on the conviction rather than the power. The establishment of an international order is made on the firm belief the legitimate rights of European rulers to be observed. Thus, confirming the thesis that the Vienna's system supports variety of forces through the principles of non-legitimacy (i.e. determined values and suppressing any attempt for revolution while still in its infancy in order not to shake Europe again).

The second basic element of Vienna's solutions is that the international order is not based on national self-determination respectively such idea within this period has not been established as a concept and tendency.

The Vienna Congress adopted two documents which express the relationship between the balance of power and the shared sense of legitimacy. The first of these two documents is the creation of an alliance between England, Austria, Prussia and Russia, whose purpose is to stop, the while still in its infancy, any attempt made by France to change the European international peace.

The second document which derived from the activities of the Vienna Congress is the creation of the Holy Alliance with a limited membership of the so-called eastern sides, and includes Russia, Austria and Prussia created by the proposal of the Russian Emperor Alexander I who motivated its creation with religious imperative that the ideas which are the basis of religions should drive the international relations. ${ }^{17}$

The above ideology of Alexander I was challenged by Maternih who transforms the ideas and proposals indicating the internal obligation of the states signatories is to preserve the status quo of Europe.

The Congress of Vienna means unification of Europe and of the deepest interests of the European nations supported by the idea of peace. For the first time Europe has a common mission to unite its people against revolutions and make them act together. European concept under the guidance of Metternich requires the emerging issues on the continent to be settled by consensus in which foundation shall be the element of moral elevation of the interrelationship between the great powers.

Led by the main postulates for creation of an international order in terms of choice of will or denial; winning or legitimacy, the activity of the Vienna Congress was made of throwing a shadow over a past in which stability derived from the internal and the political structure of force, and not out of the will. Thus the problem was not in the conflict between the reforms and the reaction, but the question was how to create order in which the change will be possible through the sense of obligation rather than with a reference to force. ${ }^{18}$

The ultimate goal and idea of the creators of the order of Vienna was to create

17 Paul, Kennedy, "The rise and fall of the Great Powers: economic change and military conflict from 1500 to 2000", Fontana Press, London, 1988. p. 183.

${ }^{18}$ Kessinger, A.Henry,"Obnovljeni svijet, Matternich ... p.214. 
a situation in which each side shall be mostly satisfied, to the extent which shall be good enough reason for any of the states and nations, so they shall not engage in revolution and struggle get what they considered their own.

\section{Conclusion}

In the century and a half between the Peace of Westphalia and the French Revolution, the map of Europe underwent few radical changes. Although it is difficult to generalize, for most of the history of early modern Europe the emergence of the modern sovereign state was obscured by the fact that the most widely prevalent form of government was monarchy. It is certain that there was no sudden transition to the modern state. Differences in the circumstances in which enlightened absolutism aroused point out one very important qualification that at the heart of the complex story of political evolution in many countries over a period of three centuries, continuity lies in the growth of the power of the state. Denying the need for proper guidance on a particular territory, consistently formulated in order to address the needs of the people, which includes, by far resisting the chaotic situation, which is typical for the lower stages of development of a society, the enlightened absolutism defines ideas, which in certain times become leading across the Europe. The very fact that the government will exist, but it shall be given to the ruler in a legitimate way, highlights the respect towards the individual who is already a product of intellectual activity and training with a tendency and motivation to increase the same and to understand itself as well as to understand the state trends. The change in the power of the state came about because of changes in ideas and because of the development to greater efficiency of well-known institutions.

The French Revolution significantly changed the meaning of the word "revolution". The revolutionaries had inherited the Enlightenment's belief in the universal abstraction of man. They felt that they were acting on behalf of all people everywhere, pitting themselves against universal tyranny. In this regard France together with Napoleon Bonaparte in the 18th century shall represent a model of successful implementation of the moment "will instead of force" by asking whether it is in fact a "disguised force as a weapon for expansion of the power trough out." However, like any model of structuring of things after a certain falls, change of generations and political conditions the same is replaced, by increasing national sentiment, imposed differently from the domestic for the reason of creation of territories placed on great distances which have unnatural features.

The basic goal of the detaching of the ideas of the enlightened absolutism was the need and the desire for peace and inner guidance of the states. In any case, the benefits of the Enlightenment as an element initially present in the 18th century, never stopped through the centuries, and further they contribute to the perception, understanding, participation in the processes, fighting and principles. 


\section{Bibliography}

1. Билјана, Поповска, Историја на правото, Скопје, 2017.

2. Birdsall, S. Viault, "Modern European History", Mc Graw Hill, Inc. 1990.

3. Ги, Антонети, „Современа политичка и општествена историја“, Арс Ламина, Скопје, 2011.

4. Eric, Hobsbawm, "The Age of Revolution 1789 - 1848", Abacus, London, 2009.

5. И. Д. Мартисевич, С. В. Јушков, Н. П. Димитриевскиј, „Општа историја државе и права““ - втор дел, Београд, 1950.

6. Иванка, Додовска, „Рамнотежата на силите и Кримската војна од 1853 - 1856 Или како геостратешките интереси на Франција и Англија го условија Виенскиот поредок? " - Политичка мисла/ Political Thought ("The Balance of Powers: 200 years of the Congress of Vienna", edition of the Konrad Adenauer Foundation and the Institute for Democracy "SocietasCivilis", Skopje, 2015.

7. Иванка, Василевска, „Версајскиот систем од 1919“, РесПублика, Скопје, 2016.

8. J.M. Kelly, A short history of western legal theory, Oxford, 1992.

9. Ј. В. Тарлеа, Историја новог века, део први, Просвета, Београд, 1948.

10. Ј. В. Тарлеа, Историја новог века, део II, Просвета, Београд, 1949.

11. J. M. Roberts, "The Penguin History of the World", Penguin Books, 1995.

12. Leften, Stavrijanos, "Balkan posle 1453 godina, Equilibrum”, Beograd 2005.

13. Paul, Kennedy, "The rise and fall of the Great Powers: economic change and military conflict from 1500 to 2000", Fontana Press, London, 1988.

14. Raino, Malnes, Knut, Midgaard, „Политичка филозофија“, Феникс, Скопје, 2003.

15. Срђан, Шаркиђ, Општа историја државе и права, Београд, 1995.

16. Филип, Лонгворт, „Стварање Источне Европе“, Clio, 2002.

17. Хари, Хердер, „Европа у деветнаестом веку“, Clio, Београд, 2003.

18. Henry, A. Kessinger, "Obnovljeni svijet, Matternich, Castlereaghi problem mira 1812-1822”, Nakladni zavod Matice Hrvatske, Zagreb 1796. 